DOI: http://dx.doi.org/10.21123/bsj.2021.18.1.0065

\title{
Evaluation of Hemolysis Activity of Zerumbone on RBCs and Brine Shrimp Toxicity
}

\author{
Shaymaa Fadhel Abbas Albaayit ${ }^{1 *}$
}

\author{
Rukesh Maharjan ${ }^{2}$
}

Mariam Khan ${ }^{3}$

${ }^{1}$ Department of Biology, College of Science, University of Baghdad, Baghdad, Iraq.

${ }^{2}$ H.e.j. Research Institute of Chemistry, International Center for Chemical and Biological Sciences, University of Karachi, Karachi, Pakistan.

${ }^{3}$ Dr Panjwani Center for Molecular Medicine and Drug Research, International Center for Chemical and Biological Sciences, University of Karachi -75270, Karachi, Pakistan.

*Corresponding authors:shaymaa_albaayit@yahoo.com ${ }^{*}, \underline{\text { rukeshmaharjan2013@gmail.com, }}$ mariam.biotech23@hotmail.com

*ORCID ID: https://orcid.org/0000-0002-8168-7048*, https://orcid.org/0000-0002-7597-7364, https://orcid.org/0000$\underline{0002-4445-8959}$

Received 23/7/2020, Accepted 22/10/2020, Published Online First 6/12/2020, Published 1/3/2021

This work is licensed under a Creative Commons Attribution 4.0 International License.

\begin{abstract}
:
Zerumbone is a well-known compound having anti-cancer, anti-ulcer, anti-inflammatory and antihyperglycemic effects. During its use for the disease treatment, the membrane of erythrocyte can be affected by consumption of this bioactive compound. The current study was the first report of investigation of the hemolytic activities on human erythrocytes and cytotoxic profile of zerumbone. The toxicity of zerumbone on human erythrocytes was determined by in vitro hemolytic assay. Brine shrimp lethality assay was used to evaluate the cytotoxic effect of zerumbone at concentrations 10,100 and $1000 \mu \mathrm{g} / \mathrm{mL}$. The human erythrocyte test showed no significant toxicity at low concentrations, whereas hemolytic effect was amplified up to $17.5 \%$ at the highest concentration. The half lethal concentration $\left(\mathrm{LC}_{50}\right)$ value of zerumbone against brine shrimp was less than $1000 \mu \mathrm{g} / \mathrm{mL}\left(\mathrm{LC}_{50}=190 \mu \mathrm{g} / \mathrm{ml}\right)$ showing the significant toxic nature of this compound. These results provide a baseline in terms of the toxicity of therapeutic formulations from this compound to membrane erythrocytes with a great attention to the highest concentrations, which paves promise for drug development.
\end{abstract}

Key words: Erythrocyte, Hemolytic activity, Toxicity, Zingiber zerumbet

\section{Introduction:}

Plant-derived bioactive compounds are well flourished for their pharmacological capacities and therapeutic actions in the prevention and treatment of different aliments. Recently, the researcher made attempts to develop drug from some potential candidates $(1,2,3)$. It is general precautionary practice to screen natural sources for their cytotoxic and hemolytic property before developing them into pharmaceutical agent as it will predict the possible toxic effects on mammalian cells (4). Zerumbone is a major bioactive compound derived from the rhizomes of Zingiber zerumbet (Smith) that has been traditionally used for the treatment of stomach ulcer, diarrhea and anti-inflammatory $(5,6)$. The methanolic and dichloromethane extract of rhizomes of $Z$. zerumbet had been reported to possess anti-larvicidal property (7), whereas the ethyl acetate extract of this plant was reported for providing protection to erythrocytes from the oxidative damage induced by hydrogen peroxide (8). In these reported manuscript, only extracts were tested, and predicted zerumbone as the possible compound responsible for these activities. Even though, several pharmacological studies on zerumbone have been reported in literature (9), the hemolytic capacity of zerumbone towards erythrocytes has not been scientifically reported yet. Thus, this study was carried out to test in vitro the effect of zerumbone on human erythrocytes and evaluated the cytotoxic activity against brine shrimp larvae.

\section{Materials and Methods: \\ Materials:}

The extraction of pure zerumbone (Fig .1) crystals from Zingiber zerumbet(L.) Smith, its 
preparation and characterization is well reported in previously published manuscript (6). Briefly, volatile oil from freshly sliced zerumbet rhizomes was extracted through steam distillation process and its crystals were obtained by using absolute hexane $100 \%$. The pure crystals of zerumbone was obtained by repeating the crystallization process thrice with absolute hexane, and stored at $4{ }^{\circ} \mathrm{C}$ until use. A stock solution $(20 \mathrm{mg} / \mathrm{mL})$ of zerumbone was made in $100 \%$ DMSO and $100 \%$ methanol for hemolysis and brine shrimp assay, respectively.

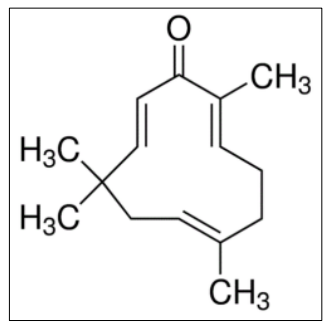

Figure 1. Chemical Structure of Zerumbone

\section{Hemocompatibility assay for zerumbone}

The lytic effects of Zerumbone were estimated according to Ghramh et al (7) with minor modifications. Three $\mathrm{mL}$ of human blood was withdrawn using anticoagulant agent EDTA (10) in compliance with Compound dissolved in $100 \%$ DMSO and then diluted in PBS for experiment, from here, $10,5,2.5 \mu \mathrm{L}$ was picked up to make 1000, 500 and $250 \mu \mathrm{g} / \mathrm{mL}$, respectively. The erythrocytes were washed three times with PBS followed by $25 \mathrm{x}$ dilution with PBS to obtain approximately $4 \%$ concentration of hematocrit. The RBCs suspension $(100 \mu \mathrm{L})$ was placed in 96-well cell culture plates in triplicates. Three concentrations of zerumbone were prepared represented in 250,500 and $1000 \mu \mathrm{g} / \mathrm{mL}$ was added to the RBCs cells and incubated at $37^{\circ} \mathrm{C}$ for 1 hour to allow for hemolysis process to take yield. After incubation, the plate was centrifuged for $10 \mathrm{~min}$ at $2500 \mathrm{rpm}$. The supernatants $(100 \mu \mathrm{L} /$ well $)$ were transferred to a new 96-well plate; the absorbance of the yield was logged at $576 \mathrm{~nm}$ in a microplate reader (MultiSkan Go, Thermo Scientific). Several wells containing RBCs suspension $(100 \mu \mathrm{L})$ were treated positive and negative control solutions, Triton X-100 (0.5\%) and PBS respectively furthermore wells examined by $2 \%$ DMSO as solvent control.

\section{Brine shrimp (Artemia ranciscana) lethality assay}

Artificial sea water at $\mathrm{pH} 7.4$ was prepared by dissolving $38 \mathrm{~g}$ of sea salt in $1 \mathrm{~L}$ of distilled water, and poured in small side of hatching tray, so that water flows to large side through holes on the partition wall. When water level is equilibrated on both sides, $25 \mathrm{mg}$ of brine shrimp egg was added on small side and covered with aluminum foil to protect from light whereas other side will be exposed to light so that grown motile larvae will move to large side from the holes in the partition wall. These active larvae were collected in jar. 10 motile nauplii per vial were added in glass vial which already contained zerumbone at different concentrations $(10,100$ and $1000 \mu \mathrm{g} / \mathrm{mL})$ dissolved in methanol, which was evaporated prior to addition of larvae. DMSO will not evaporate so it affects growth of larvae; therefore, it was not used. Then $5 \mathrm{~mL}$ of sea water was added to each vial and incubated at $27^{\circ} \mathrm{C}$ for $24 \mathrm{~h}$ under light. Next day, numbers of dead and live larvae were counted and analyzed $\%$ mortality at each concentration by using below mentioned formula and $\mathrm{LC}_{50}$ was calculated from the MS-Excel graph (11).

$\%$ mortality $=$

$\frac{\text { Number of dead larvae after } 24 \mathrm{~h}}{\text { Total number of both live and dead larvae }} \times 100$.

\section{Result:}

\section{The Lytic Effect of zerumbone on Red Blood Cells}

The percentage of hemolytic activity of zerumbone increased with increasing concentration in a dose-dependent manner. Zerumbone-induced hemolytic effect against human RBCs and promoted $17.5 \%$ of hemolysis at the highest concentration $1000 \mu \mathrm{g} / \mathrm{mL}$ was used as shown in Fig. 2.

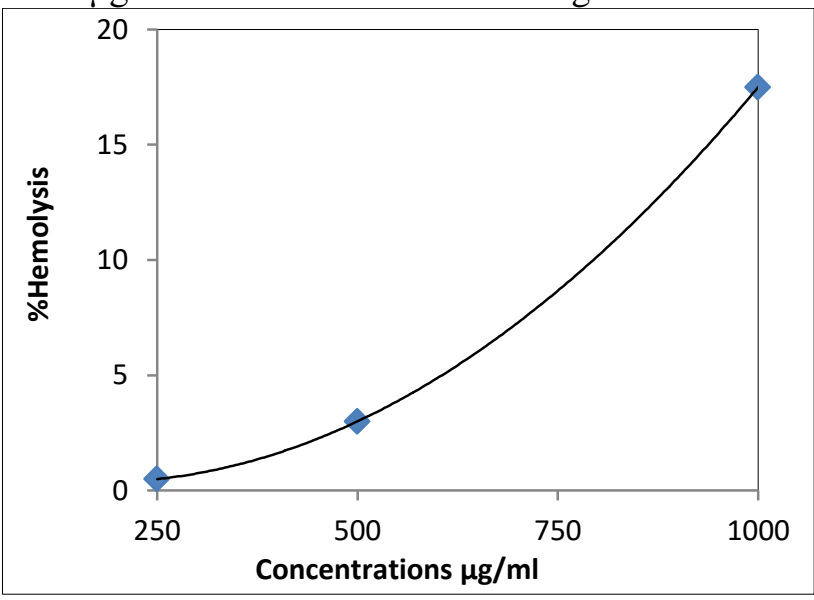

Figure 2. Hemolysis percentage of human RBCs effected by zerumbone after incubation for 60 minute.

\section{Cytotoxicity assay}

Brine shrimp lethality assay was performed for evaluation the cytotoxic nature of zerumbone. In Table 1, the result shows that the percentage mortality of brine shrimp larvae was increasing gradually and the inhibition percentage increased according to zerumbone concentrations. The 
mortality rate was considered to be $100 \%$ at concentration of $1000 \mu \mathrm{g} / \mathrm{mL}$. The $\mathrm{LC}_{50}$ value was found to be $190 \mu \mathrm{g} / \mathrm{mL}$.

Table 1. Mortality percentage of shrimp nauplii after treating with zerumbone

\begin{tabular}{cccc}
\hline $\begin{array}{c}\text { Concentration } \\
(\mu \mathrm{g} / \mathrm{mL})\end{array}$ & $\%$ Mortality & $\begin{array}{c}\mathrm{LC}_{50} \\
(\mu \mathrm{g} / \mathrm{mL})\end{array}$ & Graph \\
\hline 10 & 1 & & \\
100 & 33 & 190 & Figure 3 \\
1000 & 100 & & \\
\hline
\end{tabular}

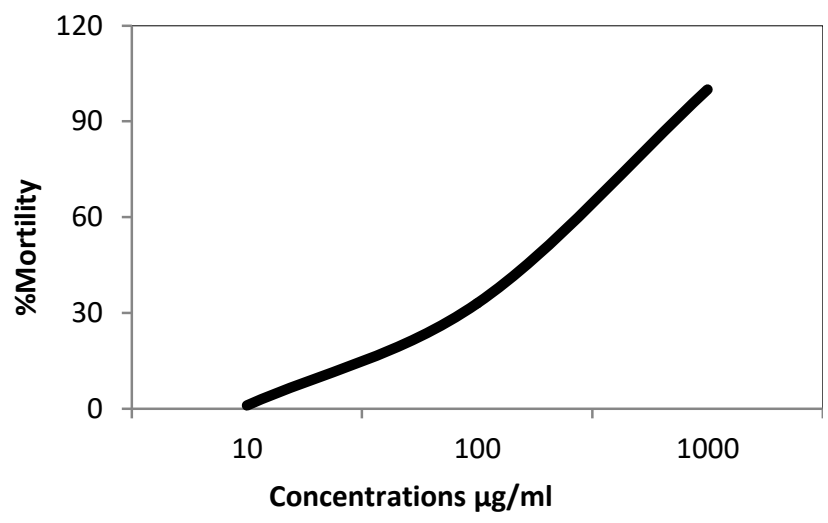

Figure 3. Mortality percentage of human RBCs effected with incubation of zerumbone for 24 hour assayed by brine shrimp nauplii larvae lethality assay

\section{Discussion:}

Since ancient time, plants have been used for the treatment of several diseases; thus, researchers are excessively interesting in the area of ethno pharmacology to develop drugs $(12,13,14,15,16,17)$. Moreover, Zerumbone has been reported as one of the most active chemotherapy against various types of cancers (18); therefore, it is important to explore on its hemolytic capacity that may be considered as interest for drug development which in turn may prevent myelosuppression, the most side effects of cancer chemotherapy (19). In the laboratory, human erythrocytes represent a good routinely model to screen the biocompatibility and biological safety of new drugs, because that blood is readily available and cells are easy to isolate from the blood (20). Nevertheless, the hemolysis assay is useful for studying the relation of injectable drugs toward plasma membrane injury and also can be used as a sensible indicator of damage against non-target cells (21). In this study, zerumbone demonstrated 4 and $17 \%$ hemolysis at 500 and $1000 \mu \mathrm{g} / \mathrm{mL}$, respectively. As the hemolysis of RBCs did not reach 25\%; therefore, it indicates that the zerumbone is relatively safe. This is in accordance with an earlier guidance on hemolysis, which says any compound possessing more than $25 \%$ hemolysis are highly risky for the hemolysis with severe side effects (20).

Due to simple and cost effective nature of Brine shrimp lethality assay, it has been extensively used to screen the toxicity level of different pesticides and natural compounds to determine the $\mathrm{LD}_{50}$ dose (22). Riaz et al., (23) who stated that substances from natural products were known as toxic if the $\mathrm{LC}_{50} \leq 1.0 \mathrm{mg} / \mathrm{mL}$. In this study, zerumbone possessed cytotoxic effect against brine shrimp larvae since the $\mathrm{LC}_{50}$ values was $190 \mu \mathrm{g} / \mathrm{mL}$. Bucker et al., (24) evaluated the methanolic and dichloromethane extract of $Z$. zerumbet rhizome against brine shrimp, Anopheles nuneztovari, and Aedes aegypti larvae. Dichloromethane extract with $\mathrm{LC}_{50}=40 \mu \mathrm{g} / \mathrm{mL}$ was more toxic than methanolic extract with $\mathrm{LC}_{50}=127$ $\mu \mathrm{g} / \mathrm{mL}$ on all three tested larvae, and even predicted zerumbone for anti-larvae activity. In pursuance of that prediction, pure zerumbone was tested on brine shrimp larvae and found its toxic nature on these larvae. As, it showed lethality against brine shrimp; therefore, it might be possible that it could also kill mosquito larvae at higher concentration which need to be confirmed experimentally.

Till date, many anti-tumor compounds had been reported against many cancers but due to their cytotoxic nature on host normal cells especially on erythrocytes made them ineligible for systemic circulation. Due to which, many compounds failed to progress in different phases of drug discovery. As zerumbone is also well known for its antitumor, anti-inflammatory property; therefore, it is necessary to check its effect of human erythrocytes. Previously, Sam et al., (8) reported the protective effect of lower dose of ethyl acetate extract of $Z$. zerumbet on RBCs that were exposed to hydrogen peroxide. Ethyl acetate extract at $6.25 \mu \mathrm{g} / \mathrm{mL}$ demonstrated the highest protection effect on RBCs from deleterious effect of hydrogen peroxide, whereas at $50 \mu \mathrm{g} / \mathrm{mL}$, it showed higher hemolysis. Therefore, this extract showed biphasic effect on erythrocytes. In this extract, they did not mention particular compound responsible for its antioxidant and pro-oxidant effect but predicted zerumbone might be responsible for this antioxidant protective effect on erythrocytes. In pursuance of that, the pure zerumbone was tested on human erythrocytes and demonstrated the non-hemolytic nature of zerumbone on human erythrocytes with higher therapeutic index.

\section{Conclusions:}

Zerumbone is a low hemolytic compound with some cytotoxic property against Artemia 
ranciscana, thus this compound possess hemocompatibility capacity to be used as therapeutic agent.

\section{Acknowledgments:}

Corresponding author is grateful to Prof. Dr. Muhammad Iqbal Choudhary (Director, International Center for Chemical and Biological Sciences, University of Karachi, Pakistan) for providing NAM-ICCBS Fellowship Award.

\section{Authors' declaration:}

- Conflicts of Interest: None.

- We hereby confirm that all the Figures and Tables in the manuscript are mine ours. Besides, the Figures and images, which are not mine ours, have been given the permission for republication attached with the manuscript.

- The author has signed an animal welfare statement.

- Ethical Clearance: The project was approved by the local ethical committee in University of Baghdad.

\section{References:}

1. Albaayit SFA, Rasedee A, Abdullah N, Abba Y. Methanolic extract of Clausena excavata promotes wound healing via antiinflammatory and antiapoptotic activities. Asian Pac J Trop Biomed. 2020;10 (5): 232-238.

2. Albaayit SFA, Al-Khafaji AS, Alnaimy HS. In vitro macrophage nitric oxide and interleukin-1 beta suppression by Moringa peregrina seed. Turk J Pharm Sci. 2019;16 (3): 362-365.

3. Al-Bahrani RM, Radif HM, Albaayit SFA. Evaluation of potent silver nanoparticles production from Agaricus bisporus against Helicobacter pylori. Pak J Agri Sci. 2020;57 (4): 1197-1201.

4. Albaayit SFA, Ozaslan M. Cytotoxic and Urease Inhibition Potential of Moringa peregrina Seed Ethanolic Extract. Int J Pharmacol. 2019;15 (1): 15115.

5. Albaayit SFA, Maharjan R. Immunomodulation of Zerumbone via Decreasing the Production of Reactive Oxygen Species from Immune Cells. Pak J Biol Sci. 2018;21 (9): 475-479.

6. Albaayit SFA, Rasedee A, Abdullah N. Zerumboneloaded nanostructured lipid carrier gel facilitates wound healing in rats. Rev Bras Farmacogn. 2020;(30):272-278.

7. Bucker A, Falcao-Bucker NC, Nunez CV, Pinheiro CC, Tadei WP. Evaluation of larvicidal activity and brine shrimp toxicity of rhizome extracts of Zingiber zerumbet (L.) Smith. Rev Soc Bras Med Tro. 2013;46 (3): 377-380.

8. Sam MF, Hamid A, Ghazali AR, Louis SR, Budin SB. Protective Effects of Zingiber zerumbet Ethyl Acetate Extract on Hydrogen Peroxide-Induced
Damage of Red Blood Cells. Sains Malays. 2019;48 (4): 781-790.

9. Ghramh HA, Khan KA, Ibrahim EH. Biological Activities of Euphorbia peplus Leaves Ethanolic Extract and the Extract Fabricated Gold Nanoparticles (AuNPs). Molecules. 2019;24 (7):1431.

10. Independent Ethics Committee of ICCBS, University of Karachi with informed consent ICCBS/IEC-028HB-2017/PROTOCOL/1.0.

11. Raza A, Muhammad F, de Sousa DP, Khaliq T, Aslam B, Andrade L, Bashir S, Anwar MI, Shahid $\mathrm{M}$, Qamar $\mathrm{M}$. In vitro and in vivo toxicological evaluations of methyl ferulate, methyl p-coumarate, and pulegone 1, 2-epoxide. Pharm biol. 2016;54 (3): 523-529.

12. Ad'hiah AH, Ibraheem RM, Abbood KW. Modulation of cytokine production from cultured mononuclear cells of leukemia patients by Hypericum triquetrifolium Turra methanolic extract. Arab J Basic Appl Sci. 2018;25 (1): 13-9.

13. Albaayit SFA, Abba Y, Abdullah R, Abdullah N. Prophylactic effects of Clausena excavata Burum. $\mathrm{f}$. leaf extract in ethanol-induced gastric ulcers. Drug des devel ther. 2016;(10):1973.

14. Albaayit SFA, Abba Y, Abdullah R, Abdullah N. Effect of Clausena excavata Burm. f.(Rutaceae) leaf extract on wound healing and antioxidant activity in rats. Drug des devel ther. 2015;(9):3507.

15. Albaayit SFA, Abba Y, Abdullah R, Abdullah N. Evaluation of antioxidant activity and acute toxicity of Clausena excavata leaves extract. Evid Based Complement Altern. 2014;975450.

16. Al-naddawi THS, Albaayit SFA, khalaf ZZ. The Synergism and Antagonism behavior of Aqueous Extraction for Black Tea, Green Tea and Coffee against the Effectiveness of Certain Antibiotics. eurasia proc sci technol eng math. 2019;6 (6): 39-42.

17. Al-Ani LKT, Yonus MI, Mahdii BA, Omer MA, Taher JK, Albaayit SFA, Al-Khoja SB. First record of use Fusarium proliferatum fungi in direct treatment to control the adult of wheat flour Tribolium confusum, as well as, use the entomopathogenic fungi Beauveria. Ecol environ conserv. 2018; 24 (3): 29-34.

18. Haque MA, Jantan I, Arshad L, Bukhari SNA. Exploring the immunomodulatory and anticancer properties of zerumbone. Food Funct. 2017;8 (10): 3410-3431.

19. Zohra M, Fawzia A. Hemolytic activity of different herbal extracts used in Algeria. Int J Pharm Sci Res. 2014;5 (8): 495-500.

20. Mahomoodally F, Mesaik A, Choudhary MI, Subratty AH, Gurib-Fakim A. In vitro modulation of oxidative burst via release of reactive oxygen species from immune cells by extracts of selected tropical medicinal herbs and food plants. Asian Pac J Trop Med. 2012;5 (6): 440-447.

21. Amin K, Dannenfelser RM. In vitro hemolysis: guidance for the pharmaceutical scientist. J pharm sci. 2006;95 (6):1173-1176. 
22. Mushtaq S, Abbasi BH, Uzair B, Abbasi R. Natural products as reservoirs of novel therapeutic agents. EXCLI J. 2018; 17: 420-451.

23. Riaz A, Rasul A, Hussain G, Zahoor MK, Jabeen F, Subhani Z, et al. Astragalin: a bioactive phytochemical with potential therapeutic activities. Adv Pharmacol Pharm Sci. 2018; 9794625.
24. Bucker A, Falcao-Bucker NC, Nunez CV, Pinheiro CC, Tadei WP.Evaluation of larvicidal activity and brine shrimp toxicity of rhizome extracts of Zingiber zerumbet (L.) Smith. Rev Soc Bras Med Tro. 2013;46 (3): 377-380.

\section{تقييم الفعالية التحللية لمركب الزرمبون في كريات الام الحمراء وسمية الارتيميا \\ 3 مريم خان \\ روكيش ماهراجا \\ شيماء فاضل عباس البياتي

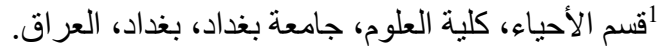

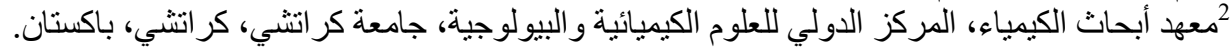 3مركز الدكتور بنجو اني للطب الجزيئي وبحوث الأدوية، المركز الدولي للعلوم الكيميائية والبيولوجية باكية، جامعة كراتثي -75270، كر اتثي،

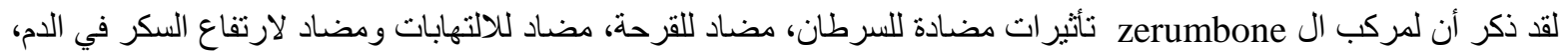

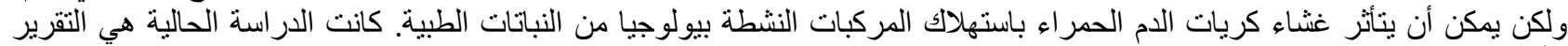

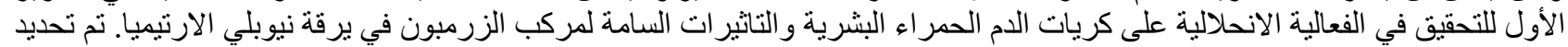

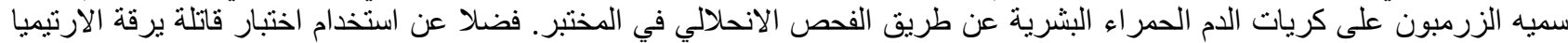

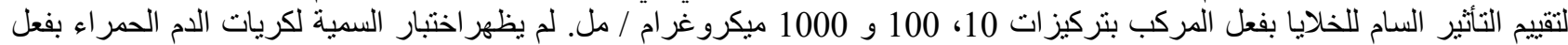

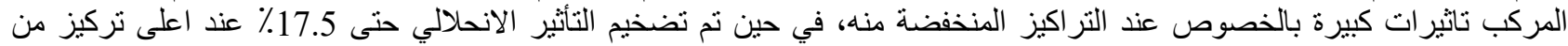

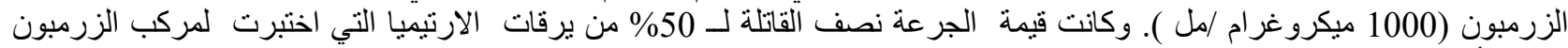

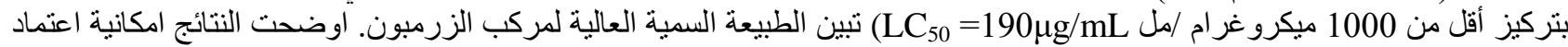

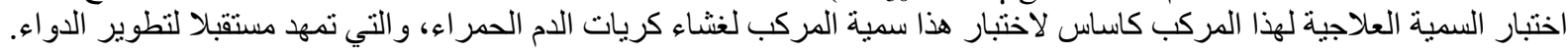

Zingiber zerumbet الكلمات المفتاحيه : النشاط الانحلالي، السمية، كريات الدم الحمر اء، 